\title{
Assessment of quality attributes of hybrids developed from pure lines of cherry and cocktail-type tomatoes
}

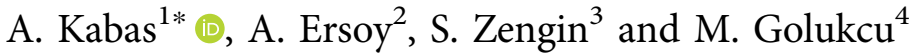 \\ ${ }^{1}$ Manavgat Vocational School, Akdeniz University, Antalya, Turkey \\ ${ }^{2}$ Antalya Directorate of Agricultural Quarantine, Antalya, Turkey \\ ${ }^{3}$ Antalya Agriculture Production Consultancy and Marketing Company, Antalya, Turkey \\ ${ }^{4}$ Bati Akdeniz Agricultural Research Institute, Antalya, Turkey
}

ORIGINAL RESEARCH PAPER

Received: May 09, 2020 • Accepted: July 29, 2020

Published online: February 16, 2021

(c) 2020 Akadémiai Kiadó, Budapest

\begin{abstract}
Tomato is worldwide the most grown vegetable. The primary target of breeding programs is to develop new tomato cultivars that are resistant to pests and diseases, in combination with high quality and yield, well-adaptation and good firmness. Among the different tomato types, cherry and cocktail tomatoes are widely preferred by consumers due to their better taste and appearance. In this study, two female tester lines were crossed with four male lines to obtain new tomato hybrids. The eight $\mathrm{F}_{1}$ hybrids and two commercial hybrids were planted in a randomised complete block design with two replications in a greenhouse in Antalya. The tomatoes of the hybrids and lines were harvested at fully ripened stage to evaluate yield, total soluble solids (TSS), fruit firmness, lycopene content and fruit colour parameters. TSS values of the cultivars and lines ranged from 4.5 to $9.5^{\circ} \mathrm{Bx}$, fruit firmness from 7.94 to $11.85 \mathrm{~kg} \mathrm{~cm}^{-2}$, lycopene from 52.10 to 55.88 $\mathrm{mg} \mathrm{kg}^{-1}$, yield from 554.3 to $1336.7 \mathrm{~g} /$ plant. Hybrid AK0020 was found the best for both yield and quality.
\end{abstract}

\section{KEYWORDS}

different type, lycopene, tomato quality, Solanum lycopersicum

\footnotetext{
*Corresponding author. Tel.: +90 2427433500, E-mail: demirelliaylin@hotmail.com
} 


\section{INTRODUCTION}

Tomato is the most important vegetable crop grown in the world. It originates from the Andean region of South America, and the time and place of domestication of tomato are not exactly known (Bai and Lindhout, 2007). Many studies showed that Solanum lycopersicum var. cerasiforme (SLC) originated from crosses between S. pimpinellifolium (SP) and S. lycopersicum L. var. lycopersicum (SLL). As a result of this, large-fruited common tomatoes could be consumed around the world (Lin et al., 2014; Razifard et al., 2020). Commercial production of tomatoes began in 1847 , and tomato became a major vegetable crop in the mid- 20th century (Foolad, 2007). Different demands had to be met for national and international markets, and different types and varieties emerged.

Widely produced types include single, beef, cluster, cherry, cocktail, plum, and processing tomato types (Kabas and Zengin, 2012). Tomato preserves, dried tomatoes, and tomato-based foods are among the processed products (Costa and Heuvelink, 2018). Tomato breeders have focused in their breeding programs to improve yield and tolerance to abiotic and biotic stresses. As a result of these breeding efforts, genetic diversity and nutritional value is reduced (Schouten et al., 2019). Many new commercial cultivars have lost their flavour and nutrient content after half a century of intensive breeding. Breeders selected modern cultivars according to growth and some other traits, but nutrient content was not included (Klee and Tieman, 2013). To develop tomato cultivars with high levels of quality criteria such as taste, aroma, colour, shape, and lycopene content is the most important task in modern breeding programs. Especially, lycopene is beneficial for human health, and tomatoes contain high levels of this antioxidant (Caseiro et al., 2020). Cherry tomatoes have higher levels of antioxidants, carotenoids, ascorbic acid, phenolic compounds and sugar contents than large-fruited tomatoes. So this type of tomato is preferred among consumers due to generally higher sugar content and concentrations of many health-promoting bioactives (Kannaujia et al., 2020). Selection for sugar and acid content can be an efficient way to breed tastier cherry tomatoes (Casals et al., 2019). Cherry tomatoes have higher sugar and acid contents than the other tomato types. Therefore, cherry and cocktail tomatoes are tastier than other tomatoes.

In this study, tomato lines with cherry and cocktail fruit types in the tomato genepool were assessed for yield and quality attributes, and contributions of both mother and father to the characteristics of the hybrid were investigated.

\section{MATERIALS AND METHODS}

Six (two female, four male) cherry and cocktail type tomato parental lines $\left(\geq \mathrm{F}_{6}\right)$ and 8 candidate cultivars were obtained after crossing two female (E18, E13) with four male lines (E3, E11, E14, E16). Combinations among the lines and the candidate hybrid cultivars are shown in Table 1. Yeniceri $\mathrm{F}_{1}$ and PTK $112 \mathrm{~F}_{1}$ were used as controls. Quality analyses were conducted on tomato lines and developed cultivars. Yield, total soluble solids $\left({ }^{\circ} \mathrm{Bx}\right)$, fruit firmness, lycopene content, and fruit colour $\left(L^{*}, a^{*}, b^{*}, C, h^{\circ}\right)$ were analysed. All quality parameters were studied with three replications, and JUMP statistical software was used for statistical analyses. 
Table 1. Different combinations generated

\begin{tabular}{lcc}
\hline Hybrid number & Female number & Male number \\
\hline AK0020 & E18 & E3 \\
AK0044 & E18 & E11 \\
AK0029 & E18 & E14 \\
AK0043 & E18 & E16 \\
AK0027 & E13 & E3 \\
AK0028 & E13 & E11 \\
AK0035 & E13 & E14 \\
AK0026 & E13 & E16 \\
\hline
\end{tabular}

\subsection{Hybridisations and seed production}

Crosses between the tomato lines of the genepool were conducted at Western Mediterranean Agricultural Research Institute ( $36^{\circ} 55^{\prime} 44.20^{\prime \prime}$ north latitude and $30^{\circ} 58^{\prime} 52.91^{\prime \prime}$ east longitude). A day before blossoming the male organs of mother plants were removed with forceps. Next day, pollen of father plants was collected into a tube with the aid of a vibrator. These pollens were spread on the stigma, and labels with hybrid number were attached. Hybridisations were performed to get 6-10 berries of each plant. Berries were harvested at the end of red-maturity stage, and seeds were collected. The berries were initially cut into half along the equilateral section. Seeds were taken with placenta into a separate container. Seeds were then fermented for two days and the placenta section was removed. Seeds were washed and dried in drying cabins. Dried seeds were enveloped and preserved in a seed storage at $5{ }^{\circ} \mathrm{C}$ and $20 \%$ relative humidity.

\subsection{Total soluble solids ( $\left.{ }^{\circ} \mathrm{Bx}\right)$}

In order to determine TSS, berries were homogenised with ultra-turrax for $1 \mathrm{~min}$ and centrifuged at 5,000 r.p.m. at $4{ }^{\circ} \mathrm{C}$ (Sigma, 2-16KL). The supernatant was used to determine TSS content by using a digital refractometer (A. Krüss Optronic GmbH, DR6000 series, Germany) at $20{ }^{\circ} \mathrm{C}$.

\subsection{Fruit flesh firmness $\left(\mathrm{kg} \mathrm{cm}^{-2}\right)$}

Flesh firmness was measured directly on 3 different points along the equilateral section of each berry with the aid of a penetrometer (Brookfield, CT3 Texture Analyser) with $4 \mathrm{~mm}$ penetrating tip.

\subsection{Lycopene content ( $\left.\mathrm{mg} \mathrm{kg}^{-1}\right)$}

Tomato pulp $(0.5 \mathrm{~g})$ was placed into $50 \mathrm{~mL}$ centrifuge tubes and supplemented with $5 \mathrm{ml}$ acetone (0.05\% BHT), $5 \mathrm{~mL} 95 \%$ ethanol and $10 \mathrm{~mL}$ hexane. Samples were shaken in an orbital shaker at 180 r.p.m. for $15 \mathrm{~min}$. After adding $3 \mathrm{~mL}$ distilled water, the samples were further shaken for $5 \mathrm{~min}$ and stored until phase separation. Samples were taken from the upper phase, and absorbance readings were performed at $503 \mathrm{~nm}$ wavelength on a UV-Vis spectrophotometer (Shimadzu, UV-1800, Japan). Resultant absorbance value was used in the following equation to calculate lycopene content of the sample (Fish et al., 2002): 


$$
\text { Lycopene content }\left(\mathrm{mg} \mathrm{kg}^{-1}\right)=\left(A_{503} \times 31.2 / W\right) / g
$$

where $W=$ sample quantity, $A_{503}$ : absorbance read at $503 \mathrm{~nm}$

\subsection{Fruit colour}

CIE Lab colour values were measured with a Chroma Meter CR-400 device (Konica Minolta Sensing Inc., Japan). Colour measurements were performed on the surface of the fruit from three different points under $D_{65}$ light source for each fruit and three berries were used for each replication. Before the measurements, the device was calibrated with a white ceramic calibration plate (CR-A43) and the measurements were performed over a white platform. $L^{*}$ indicates whitenessblackness with values ranging from 0 (black) to 100 (white); $a^{*}$ indicates greenness-redness with values ranging from -60 (green) to +60 (red); $b^{*}$ indicates blueness-yellowness with values ranging from -60 (blue) to +60 (yellow) (Ozdemir, 2001). The colour index $C$ value (Chroma) of the samples was calculated with the formula $C=\left(a^{2}+b^{2}\right)^{0.5}$, and the hue angle $h^{\circ}=\arctan (b / a)$.

\subsection{Yield experiments}

In yield experiments, hybrid combinations obtained through hybridisations, lines, and two commercial cultivars (Yeniceri $\mathrm{F}_{1}$ and PTK $112 \mathrm{~F}_{1}$ ) were used. Greenhouse experiments were conducted in 2 replicates with 20 plants in each replicate.

\subsection{Data analysis}

For statistical analyses $t$ test method was used at $P<0.05$ probability.

\section{RESULTS AND DISCUSSION}

\subsection{Quality analyses}

TSS, fruit firmness, lycopene content, $L^{*}, a^{*}, b^{*}, C$, and $h^{\mathrm{o}}$ values of the cultivars are presented in Tables 2 and 3 .

Table 2. TSS, firmness, lycopene, and $L^{*}, h^{\circ}$ values of the cultivars

\begin{tabular}{lccccc}
\hline Hybrid number & TSS $\left({ }^{\circ} \mathrm{Bx}\right)$ & Firmness $\left(\mathrm{kg} \mathrm{cm}^{-2}\right)$ & Lycopene $\left(\mathrm{mg} \mathrm{kg}^{-1}\right)$ & $L^{*}$ & $h^{\text {o }}$ \\
\hline AK0020 & $5.3 \mathrm{~b}$ & $10.75 \mathrm{bc}$ & $42.99 \mathrm{e}$ & $41.51 \mathrm{a}$ & $50.69 \mathrm{a}$ \\
AK0029 & $5.8 \mathrm{a}$ & $9.04 \mathrm{f}$ & $46.76 \mathrm{c}$ & $38.15 \mathrm{bc}$ & $46.54 \mathrm{be}$ \\
AK0043 & $5.9 \mathrm{a}$ & $10.2 \mathrm{~d}$ & $43.55 \mathrm{e}$ & $37.96 \mathrm{bc}$ & $45.08 \mathrm{de}$ \\
AK0044 & $5.7 \mathrm{a}$ & $9.55 \mathrm{e}$ & $41.04 \mathrm{f}$ & $38.17 \mathrm{bc}$ & $47.21 \mathrm{bc}$ \\
Yeniceri F & $5.65 \mathrm{a}$ & $7.94 \mathrm{~h}$ & $55.88 \mathrm{a}$ & $36.88 \mathrm{c}$ & $44.79 \mathrm{e}$ \\
PTK 112 $\mathrm{F}_{1}$ & $4.5 \mathrm{~d}$ & $8.40 \mathrm{~g}$ & $48.89 \mathrm{~b}$ & $37.92 \mathrm{bc}$ & $46.91 \mathrm{bd}$ \\
AK0026 & $5.7 \mathrm{a}$ & $9.39 \mathrm{e}$ & $45.03 \mathrm{~d}$ & $38.95 \mathrm{ac}$ & $46.13 \mathrm{be}$ \\
AK0027 & $5.0 \mathrm{c}$ & $10.55 \mathrm{c}$ & $56.13 \mathrm{a}$ & $40.30 \mathrm{ab}$ & $48.09 \mathrm{~b}$ \\
AK0028 & $4.95 \mathrm{c}$ & $11.85 \mathrm{a}$ & $48.82 \mathrm{~b}$ & $38.86 \mathrm{ac}$ & $45.33 \mathrm{ce}$ \\
AK0035 & $4.5 \mathrm{~d}$ & $10.92 \mathrm{~b}$ & $55.39 \mathrm{a}$ & $38.74 \mathrm{ac}$ & $47.01 \mathrm{bd}$ \\
CV & 1.12 & 0.12 & 0.45 & 1.30 & 0.82 \\
LSD & 0.13 & 0.04 & 20.26 & 1.12 & 0.87 \\
\hline
\end{tabular}

Different letters in a column indicate statistically significant differences at $P<0.05$. 
Table 3. TSS, lycopene, $L^{*}, a^{*}, b^{*}, C$, and $h^{\circ}$ values of the lines

\begin{tabular}{lccccccc}
\hline Line number & TSS $\left({ }^{\circ} \mathrm{Bx}\right)$ & Lycopene $\left(\mathrm{mg} \mathrm{kg}^{-1}\right)$ & $L^{*}$ & $a^{*}$ & $b^{*}$ & $C$ & $h^{\circ}$ \\
\hline E18 & $9.5 \mathrm{a}$ & $66.3 \mathrm{c}$ & $39.7 \mathrm{~b}$ & $25.1 \mathrm{c}$ & $15.7 \mathrm{~d}$ & $29.3 \mathrm{~d}$ & $31.3 \mathrm{~g}$ \\
E13 & $8.9 \mathrm{~b}$ & $65.7 \mathrm{c}$ & $36.4 \mathrm{~g}$ & $22.8 \mathrm{~d}$ & $16.4 \mathrm{~d}$ & $27.8 \mathrm{e}$ & $36.1 \mathrm{f}$ \\
E3 & $8.1 \mathrm{c}$ & $90.9 \mathrm{a}$ & $37.4 \mathrm{e}$ & $28.7 \mathrm{a}$ & $21.5 \mathrm{~b}$ & $35.7 \mathrm{a}$ & $36.5 \mathrm{f}$ \\
E11 & $6.1 \mathrm{~d}$ & $87.4 \mathrm{~b}$ & $38.8 \mathrm{c}$ & $26.5 \mathrm{~b}$ & $21.0 \mathrm{~b}$ & $32.9 \mathrm{~b}$ & $38.1 \mathrm{e}$ \\
Yeniceri $\mathrm{F}_{1}$ & $5.6 \mathrm{e}$ & $55.8 \mathrm{e}$ & $36.8 \mathrm{f}$ & $21.5 \mathrm{ef}$ & $21.1 \mathrm{~b}$ & $29.8 \mathrm{~d}$ & $44.7 \mathrm{c}$ \\
E16 & $5.5 \mathrm{e}$ & $52.1 \mathrm{f}$ & $36.8 \mathrm{f}$ & $22.1 \mathrm{de}$ & $19.7 \mathrm{c}$ & $29.8 \mathrm{~d}$ & $42.2 \mathrm{~d}$ \\
E14 & $4.9 \mathrm{f}$ & $62.5 \mathrm{~d}$ & $40.3 \mathrm{a}$ & $20.9 \mathrm{f}$ & $23.6 \mathrm{a}$ & $31.6 \mathrm{c}$ & $48.1 \mathrm{a}$ \\
PTK 112 $\mathrm{F}_{1}$ & $4.5 \mathrm{~g}$ & $48.8 \mathrm{~g}$ & $37.9 \mathrm{~d}$ & $22.4 \mathrm{de}$ & $23.6 \mathrm{a}$ & $32.6 \mathrm{~b}$ & $46.9 \mathrm{~b}$ \\
CV & 1.09 & 0.38 & 0.29 & 1.9 & 2.41 & 0.97 & 0.54 \\
LSD & 0.17 & 0.60 & 0.26 & 1.08 & 1.16 & 0.72 & 0.52 \\
\hline
\end{tabular}

Different letters in a column indicate statistically significant differences at $P<0.05$.

\subsection{TSS}

Total soluble solids content of tomato varies with environmental conditions and genotypes (Gautier et al., 2005). TSS values of the lines varied between 4.5 and $-9.5{ }^{\circ} \mathrm{Bx}$ with the highest values from lines E18 (9.5), E13 (8.9), and E3 (8.1). Majority of present lines had higher values than the control cultivars. TSS values of the hybrids varied between 4.5 and $-5.9{ }^{\circ} \mathrm{Bx}$ with the highest values from cultivars AK0043 (5.9), AK0029 (5.8), and AK0044 (5.7) and the lowest values from PTK $112 \mathrm{~F}_{1}$ (4.5), AK0028 (4.9), and AK0027 (5.0). TSS values of the control cultivars were 4.5 (PTK $112 \mathrm{~F}_{1}$ ) and 5.65 (Yeniceri $\mathrm{F}_{1}$ ). Tomato TSS contents were between 5 and $-9{ }^{\circ} \mathrm{Bx}$ (Davies et al., 1981). In our study, TSS values of the lines varied between 4.9 and $-9.5{ }^{\circ} \mathrm{Bx}$. Among the hybrids, candidate cultivar AK0043, obtained through hybridisation of line E18 with the highest ${ }^{\circ} \mathrm{Bx}$ value (9.6) and line E16 (5.5), had the highest TSS value (5.9). TSS values of 3 other hybrids (AK0029, AK0044, and AK0020) created with the same mother line were respectively 5.8, 5.7 and 5.3. Causse et al. (2002) investigated genetic variations in quality attributes of tomatoes and determined several hybrid quality attributes as the average of parents. Total soluble solid content is highly and positively correlated with fruit weight (Casals et al., 2019). The content of total soluble solids increased during different storage regimes (Kanski et al., 2020). Today, breeding programs are mostly focused on taste and aroma. The cultivars with high ${ }^{\circ} \mathrm{Bx}$ values are preferred both by breeders and consumers.

\subsection{Fruit flesh firmness $\left(\mathrm{kg} \mathrm{cm}^{-2}\right)$}

The differences between flesh firmness of the lines were not significant. Flesh firmness of the hybrids varied between 7.94 and $11.85 \mathrm{~kg} \mathrm{~cm}^{-2}$ with the highest values in cultivars AK0028 (11.85 kg cm $\left.{ }^{-2}\right)$, AK0035 (10.92 kg cm $\left.{ }^{-2}\right)$, and AK0020 (10.75 kg cm ${ }^{-2}$ ) and the lowest values in Yeniceri $\mathrm{F}_{1}\left(7.94 \mathrm{~kg} \mathrm{~cm}^{-2}\right)$, PTK112 $\mathrm{F}_{1}\left(8.40 \mathrm{~kg} \mathrm{~cm}^{-2}\right)$, and AK0029 $\left(9.04 \mathrm{~kg} \mathrm{~cm}^{-2}\right)$. Fandi et al. (2008) reported fruit flesh firmness between 1.2 and $2.0 \mathrm{~kg} \mathrm{~cm}^{-2}$.

\subsection{Lycopene content $\left(\mathrm{mg} \mathrm{kg}^{-1}\right)$}

Lycopene content of the lines varied between 52.1 and $-90.9 \mathrm{mg} \mathrm{kg}^{-1}$ with the highest values in lines E3 $\left(90.9 \mathrm{mg} \mathrm{kg}^{-1}\right)$, E11 $\left(87.4 \mathrm{mg} \mathrm{kg}^{-1}\right)$, and E13 $\left(65.7 \mathrm{mg} \mathrm{kg}^{-1}\right)$ and the lowest values in 
line E16 (52.1 mg kg-1). Lycopene content of the hybrids varied between 41.04 and $56.13 \mathrm{mg} / \mathrm{kg}^{-1}$ with the highest values in cultivars AK0027 (56.13 $\mathrm{mg} \mathrm{kg}^{-1}$ ), Yeniceri $\mathrm{F}_{1}\left(55.88 \mathrm{mg} \mathrm{kg}^{-1}\right)$, and PTK112 $\mathrm{F}_{1}\left(48.89 \mathrm{mg} \mathrm{kg}^{-1}\right)$ and the lowest values in AK0044 (41.04 mg $\mathrm{kg}^{-1}$ ), AK0020 (42.99 $\mathrm{mg} \mathrm{kg}^{-1}$ ), and AK0043 (43.55 $\mathrm{mg} \mathrm{kg}^{-1}$ ). Ripe tomato berries contain lycopene, which is a good dietary antioxidant (Rosati et al., 2000). Khan et al. (2006) reported lycopene contents between 5.4 and $-18.8 \mathrm{mg} \mathrm{kg}^{-1}$, and showed that lycopene content was influenced by several environmental factors. Kuti and Konuru (2005) conducted a study with different tomato types, and reported the highest lycopene contents in cherry tomatoes. While the lycopene content of cherry tomatoes varied between 48.9 and $-63.6 \mathrm{mg} \mathrm{kg}^{-1}$ in greenhouses, the values varied between 73.8 and $-116.7 \mathrm{mg} \mathrm{kg}^{-1}$ in open fields. It was indicated that genotype and environmental conditions have significant effects on lycopene content. The hybrids obtained from crosses of high lycopene lines yielded average lycopene contents. Present findings confirmed that lycopene contents were influenced by genotypes in combination with other factors.

\subsection{Fruit colour}

The $a^{*}$ values varied between 20.9 and 28.7 and $b^{*}$ values varied between 15.7 and 23.6. The $a^{*}$ and $b^{*}$ colour values should not be assessed alone, $h^{\circ}$ and $C$ values are calculated with the use of $a^{*}$ and $b^{*}$ values. Fruit hue angle $\left(h^{\circ}\right)$ values were calculated as between 31.3 and -48.1 . The highest chroma $(C)$ value (35.7) was obtained from line E3 and the lowest value (29.3) was obtained from line E18.

$L^{*}, a^{*}, b^{*}, h^{\circ}$ and $C$ values were also taken into consideration for colour values of hybrids. The lowest $\mathrm{L}^{*}$ (brightness) value (36.88) was observed in Yeniceri $\mathrm{F}_{1}$ and the highest value (41.51) was observed in AK0020. The $a^{*}$ values varied between 4.20 and -35.04 and $b^{*}$ values varied between 13.94 and -27.4 . The $a^{*}, b^{*}$ and $C$ colour values were evaluated not significant. Fruit hue angle $\left(h^{\circ}\right)$ values were calculated as between 44.79 and -50.69 with the highest value in candidate cultivar AK0020 (50.69) followed by candidate cultivars AK0027 (48.09) and AK0044 (47.21).

Fruit colour may reveal information about lycopene and phenolics of tomato fruit. Kuti and Konuru (2005) reported $h^{\circ}$ values of 9 tomato cultivars as between 43.20 and -60.40 and $C$ values as between 30.70 and -38.10 . Present findings comply with those earlier ones.

\subsection{Yield}

Among the lines, the highest yield (1003.9 g/plant) was obtained by line E3. Following the control cultivars, the highest yield (1004.16 g/plant) was obtained from hybrid AK0020, hybrid AK0029 (994.70 g/plant), and hybrid AK0035 (884.12 g/plant) (Table 4). The candidate cultivar AK0020, obtained through hybridisation of high-yield line E18 with the line E3, had the highest yield. Similarly, candidate cultivars AK0028 and AK0041, obtained through hybridisations with low-yield line E13, had the lowest yields. Yield is the most significant selection criterion in tomatoes. Plant morphology, physiology, growing conditions, genotype, abiotic and biotic stressors are the primary factors influencing yields in tomatoes (Causse et al., 2007). Solieman et al. (2013) reported that total fruit yield per plant was inherited by dominance or over dominance. In hybrid breeding, yield can be used together with fruit quality to improve the performance of tomatoes (Hannan et al., 2007). Inheritance of yield and yield components may reveal significant information for the selection of proper lines to develop high-yield cultivars 
Table 4. Yield value of hybrids and lines

\begin{tabular}{lccc}
\hline Hybrid number & Yield (g/plant) & Line number & Yield (g/plant) \\
\hline AK0020 & $1004.16 \mathrm{~b}$ & $\mathrm{E} 18$ & $904.5 \mathrm{~d}$ \\
AK0029 & $994.70 \mathrm{bc}$ & $\mathrm{E} 13$ & $935.0 \mathrm{~d}$ \\
AK0043 & $812.66 \mathrm{de}$ & $\mathrm{E} 3$ & $1003.9 \mathrm{c}$ \\
AK0044 & $749.04 \mathrm{e}$ & E11 & $910.0 \mathrm{~d}$ \\
Yeniceri F $F_{1}$ & $1220.70 \mathrm{a}$ & Yeniceri $\mathrm{F}_{1}$ & $1220.7 \mathrm{~b}$ \\
PTK 112 F & E16 & $935.0 \mathrm{~d}$ \\
AK0026 & $1336.65 \mathrm{a}$ & E14 & $935.0 \mathrm{~d}$ \\
AK0027 & $828.12 \mathrm{de}$ & PTK 112 $\mathrm{F}_{1}$ & $1336.6 \mathrm{a}$ \\
AK0028 & $830.58 \mathrm{de}$ & CV & 2.05 \\
AK0035 & $554.33 \mathrm{f}$ & LSD & 49.69 \\
CV & $884.12 \mathrm{~cd}$ & & \\
LSD & 2.24 & & \\
\hline
\end{tabular}

Different letters in a column indicate statistically significant differences at $P<0.05$.

(Zdravković et al., 2011). In present study, hybrid cultivar AK0020 was selected for both yield and the quality attributes.

\section{CONCLUSIONS}

The primary target of breeding programs is not only to develop new tomato cultivars resistant to pests and diseases, but also to develop new hybrids with high quality, high yield, good fruit-set, good adaptation, high firmness and long shelf life. The most significant phase of hybrid cultivar development is the selection of the best parents. Based on market demands, quality attributes and differences in fruit, the candidate cultivars with the best performance can be included in breeding programs.

In our study, yield, total soluble solids $\left({ }^{\circ} \mathrm{Bx}\right)$, fruit firmness, lycopene content, fruit colour $\left(L^{*}, a^{*}, b^{*}, C, h^{\circ}\right)$ parameters of hybrids and tomato lines were analysed. TSS values of the AK0020, E18, and E3 were evaluated as 5.3, 9.5 and $8.1^{\circ} \mathrm{Bx}$, lycopene content was determined as 42, 99, 66.3 and $90.9 \mathrm{mg} \mathrm{kg}^{-1}$; yield was found 1004.1, 904.5 and $1003.9 \mathrm{~g} /$ plant, respectively. It was found that there was no statistically significant correlation between lines and fruit firmness.

Consequently, we determined that candidate cultivar AK0020 was the best combination for both yield as for quality attributes.

\section{REFERENCES}

Bai, Y. and Lindhout, P. (2007). Domestication and breeding of tomatoes: what have we gained and what can we gain in the future? Annals of Botany, 100(5): 1085-1094.

Casals, J., Rivera, A., Sabaté, J., Romero Del Castıllo, R., and Simó, J. (2019). Cherry and fresh market tomatoes: differences in chemical, morphological, and sensory traits and their implications for consumer acceptance. Agronomy, 9(1): 9. 
Caseiro, M., Ascenso, A., Costa, A., Creagh-Flynn, J., Johnson, M., and Simões, S. (2020). Lycopene in human health. LWT - Food Science and Technology, 127: 109323.

Causse, M., Saliba Colombani, V., Lecomte, L., Duffe, P., Rouselle, P., and Buret, M. (2002). QTL analysis of fruit quality in fresh market tomato: a few chromosome region control the variation of sensory and instrumental traits. Journal of Experimental Botany, 53(377): 2089-2098.

Causse, M., Chaib, J., Lecomte, L., Buret, M., and Hospital, F. (2007). Both additivity and epistasis control the genetic variation for fruit quality traits in tomato. TAG. Theoretical and Applied Genetics. Theoretische und angewandte Genetik, 115: 429-442.

Costa, J.M. and Heuvelink, E. (2018). The global tomato industry. in: Heuvelink, E. (Ed.), Tomatoes. 2nd ed., CABI, Boston, USA, pp. 1-26.

Davies, J.N., Hobson, G.E., and McGlasson, W.B. (1981). The constituents of tomato fruit - the influence of environment, nutrition, and genotype. Critical Reviews in Food Science and Nutrition, 15(3): 205-280.

Fandi, M., Al-Muhtaseb, J.A., and Hussein, M.A. (2008). Yield and fruit quality of tomato as affected by the substrate in an open soilless culture. JSLS: Journal of the Society of Laparoendoscopic Surgeons, 4: 65-72.

Fish, W.W., Perkins-Veazie, P., and Collins, J.K. (2002). A quantitative assay for lycopene that utilizes reduced volumes of organic solvents. Journal of Food Composition and Analysis, 15: 309-317.

Foolad, M.R. (2007). Genome mapping and molecular breeding of tomato. International Journal of Plant Genomics, 2007: Article ID 64358, 52 pages.

Gautier, H., Rocci, A., Buret, M., Grasselly, D., Dumas, Y., and Causse, M (2005). Effect of photoselective filters on the physical and chemical traits of vineripened tomato fruits. Canadian Journal of Plant Science, 85: 439-446.

Hannan, M.M., Biswas, M.K., Ahmed, M.B., Hossain, M., and Islam, R. (2007). Combining ability analysis of yield and yield components in tomato (Lycopersicon esculentum mill.). Turkish Journal of Botany, 31(6): 559-563.

Kabas, A. and Zengin, S. (2012). Ortualti yetistiriciligine uygun domates cesit islahi (Breeding of tomato F1 hybrid for greenhouses). 9. Ulusal Sebze Tarimi Sempozyumu (National Vegetable Agriculture Symposium), pp. 60-67.

Kannaujia, P.K., Patel, N., Asrey, R., Mahawar, M.K., Meena, V.S, Bibwe, B., Jalgaonkar, K., and Negi, N. (2020). Variability of bioactive properties and antioxidant activity in commercially grown cherry tomato (Solanum lycopersicum var. cerasiforme) cultivars grown in India. Acta Alimentaria, 49: 13-22.

Kanski, L., Naumann, M., and Pawelzik, E. (2020). Flavor-related quality attributes of ripe tomatoes are not significantly affected under two common household conditions. Facial Plastic Surgery: FPS, 11, article 472.

Khan, M.M.A., Gautam, C., Mohammad, F., Siddiqui, M.H., Naeem, M., and Khan, M.N. (2006). Effect of gibberellic acid spray on performance of tomato. Turkish Journal of Botany, 30(1): 11-16.

Klee, H.J. and Tieman, D.M. (2013). Genetic challenges of flavor improvement in tomato. Tropical Gastroenterology: Official Journal of the Digestive Diseases Foundation, 29(4): 257-262.

Kuti, J.O. and Konuru, H.B. (2005). Effects of genotype and cultivation environment on lycopene content in red-ripe tomatoes. Journal of the Science of Food and Agriculture, 85: 2021-2026.

Lin, T., Zhu, G., Zhang, J., Xu, X., Yu, Q., Zheng, Z., Zhang, Z., Lun, Y., Li, S., Wang, X., Huang, Z., Li, J., Zhang, C., Wang, T., Zhang, Y., Wang, A., Zhang, Y., Lin, K., Li, C., Xiong, G., Xue, Y., Mazzucato, A., Causse, M., Fei, Z., Giovannoni, J.J., Chetelat, R.T., Zamir, D., Städler, T., Li, J., Ye, Z., Du, Y., and Huang, S. (2014). Genomic analyses provide insights into the history of tomato breeding. Nature Genetics, 46: 1220-1226. 
Ozdemir, M. (2001). Mathematical analysis of color changes and chemical parameters of roasted hazelnuts. Ph.D. Thesis. Istanbul Technical University, 161 pages.

Razifard, H., Ramos, A., Della Valle, A.L., Bodary, C., Goetz, E., Manser, E.J., Li, X., Zhang, L., Visa, S., Tieman, D., van der Knaap, E., and Caicedo, A.L. (2020). Genomic evidence for complex domestication history of the cultivated tomato in Latin America. Molecular Biology and Evolution, 37(4): 1118-1132.

Rosati, C., Aquilani, R., Dharmapuri, S., Pallara, P., Marusic, C., Tavazza, R., Bouvier, F., Camara, B., and Giuliano, G. (2000). Metabolic engineering of betacarotene and lycopene content in tomato fruit. The Plant Journal: for Cell and Molecular Biology, 24(3): 413-419.

Schouten, H.J., Tikunov, Y., Verkerke, W., Finkers, R., Bovy, A., Bai, Y., and Visser, R.G. (2019). Breeding has increased the diversity of cultivated tomato in The Netherlands. Facial Plastic Surgery: FPS, 10: 1606.

Solieman, T., El-Gabry, M., and Abido, A. (2013). Heterosis, potence ratio and correlation of some important characters in tomato (Solanum lycopersicum L.). Scientia Horticulturae, 150: 25-30.

Zdravkovic, J., Pavlovic, N., Girek, Z., Milka, B.J., Savic, D., Zdravković, M., and Cvikic, D. (2011). Generation mean analysis of yield component and yield in tomato (Lycopersicon esculentum Mill.). Pakistan Journal of Botany, 43: 1575-1580. 